\title{
Review on Smart Practices and Technologies for Climate Resilient Agriculture
}

\author{
K. Mohan Kumar ${ }^{\text {* }}$, M. Hanumanthappa ${ }^{2}$, Narayan S. Mavarkar ${ }^{1}$ and S. Marimuthu ${ }^{3}$ \\ ${ }^{1}$ Department of Agronomy, UAHS, Shivamogga - 577204, Karnataka, India \\ ${ }^{2}$ College of Horticulture, Mudigere, Karnataka, India \\ ${ }^{3}$ Department of Agronomy, TNAU, Coimbatore, Tamil Nadu, India \\ *Corresponding author
}

\begin{abstract}
A B S T R A C T
Keywords

Technologies, Climate Resilient

Agriculture,

Climate change

Article Info

Accepted:

22 May 2018

Available Online:

10 June 2018

Climate change has become an important area of concern to ensure food and nutritional security for growing population. In India, significant negative impacts have been implied with medium-term (2010-2039) climate change, predicted to reduce yields by 4.5 to $9 \%$, depending on the magnitude and distribution of warming. In the context of climate change and variability, farmers need to adapt quickly to enhance their resilience to increasing threats of climatic variability such as droughts, floods and other extreme climatic events. Concentrated efforts are required for mitigation and adaptation to reduce the vulnerability of agriculture to the adverse impacts of climate change and making it more resilient. As most of our farmers are marginal their adaptive capacity is limited, and hence, economically viable and culturally acceptable adaptation techniques need to be developed and implemented. Over the years, an array of practices and technologies have been developed by researchers towards fostering stability in agricultural production against the onslaught of seasonal variations. Adoption of such resilient practices and technologies by farmers appears to be more a necessity than an option. Practices revolving around efficient resource-use, safeguards environment, and sustaining long-term development of agriculture assume greater importance. On-farm demonstration of site-specific technologies will go a long way in enabling farmers cope with current climate variability.
\end{abstract}

\section{Introduction}

Agriculture is crucial for food, nutritional and livelihood security of India. It engages almost two-third of the workforce in gainful employment and accounts for a significant share in India`s GDP. Several industries depend on agricultural production for their requirement of raw materials. Due to its close linkages with other economic sectors, growth in agricultural sector has a multiplier effect on the economy of the country.

The Indian agriculture has a significant progress in recent years. However, currently it is facing the challenges of stagnating net sown area, deteriorating land quality, reducing per capita land availability and growing climate change. The problem is highly challenging because $80 \%$ of our farmers are small 
(cultivating 1-2 hectares land) and marginal (cultivating up to 1 hectares land) with poor coping capacity. The farms are diverse, heterogeneous and unorganized. Indian agriculture, almost $60 \%$ of its net cultivated area as rainfed, is exposed to stresses arising from climatic variability and climate change. India has the unenviable problem of ensuring food security for the projected most populous country in 2050 with one of the largest malnourished populations.

Climate change pertains to increase in atmospheric concentration of carbon dioxide (CO) and global warming. Present day atmospheric $\mathrm{CO}_{2}$ level hovers around 397 ppm which is a significant increase over the preindustrial level of $280 \mathrm{ppm}$. It is anticipated that the concentration level will double by the end of this century (IPCC, 2007). A consequence of increased greenhouse gas (GHG) emissions is the entrapment of heat within the earth's atmosphere leading to an alarming rate of global warming. Global average increase in mean annual temperatures is estimated at $0.8^{\circ} \mathrm{C}$ till now. An increasing rate of warming has taken place across sampling areas spread across the globe over the last 25 years. For example 11 of the 12 warmest years on record have occurred in the 1996-2005 period (IPCC, 2007). Global mean temperatures are likely to witness significant increase towards the end of this century. Between seasons, warming in the rainy season will be less pronounced than in the winter months in India (IMD, 2010). Another climate change feature significantly influencing agro ecosystems is the change in seasonal rainfall patterns. Increased frequency in occurrence of extreme weather events such as cyclones, heat wave, cold wave, frost and hail storm over short periods exert adverse influence on crop performance.

Rainfall is predicted to be highly erratic with fewer rainy days but with greater intensity. A combination of higher average annual temperatures and water stress (excess or deficit) can have serious implications for crop production in the tropics. The frequency of occurrence of extreme weather events such as tropical cyclones and heat waves is on the rise (NATCOM, 2004; IPCC, 2007) and compounds the adverse effects on agriculture.

\section{Climate change threats to Indian Agriculture}

Climate change impacts on agriculture are being witnessed all over the world, but countries like India are more vulnerable in view of the huge population dependent on agriculture, excessive pressure on natural resources and poor coping mechanisms. The warming trend in India over the past 100 years has indicated on increase of $0.60^{\circ} \mathrm{C}$. The projected impacts are likely to further aggravate field fluctuations of many crops thus impacting food security.

There are already evidences of negative impacts on yield of wheat and paddy in parts of India due to increased temperature, water stress and reduction in number of rainy days. Significant negative impacts have been projected with medium-term (2010-2039) climate change, eg. Yield reduction by 4.5 to $9 \%$, depending on the magnitude and distribution of warming.

Since agriculture makes up roughly $15 \%$ of India's GDP, a 4.5 to $9.0 \%$ negative impact on production implies cost of climate change to be roughly at $1.5 \%$ of GDP per year. Enhancing agricultural productivity, therefore, is critical for ensuring food and nutritional security for all, particularly the resource poor small and marginal farmers who would be affected most. In the absence of planned adaptation, the consequences of long- term climate change could be severe on the livelihood security of the poor. 


\section{Challenges before us}

Land is shrinking but population is increasing. We need to feed that population with this land, which would be affected by flood or drought.

So farmers need to intelligently adapt to the changing climate in order to sustain crop yields and farm income. Enhancing resilience of agriculture to climate risk is of paramount importance for protecting livelihoods of small and marginal farmers. Traditionally, technology transfer in agriculture has aimed at enhancing farm productivity. However, in the context of climate change and variability, farmers need to adapt quickly to enhance their resilience to increasing threats of climatic variability such as droughts, floods and other extreme climatic events. Over the years, an array of practices and technologies have been developed by researchers towards fostering stability in agricultural production against the onslaught of seasonal variations. Adoption of such resilient practices and technologies by farmers appears to be more a necessity than an option. Therefore, a reorientation in technology transfer approach is necessary. Efficiency in resource-use, environmental and social safeguards, sustainability and long-term development of agriculture assume greater importance.

\section{Necessity to adapt to climatic vulnerability}

Planned adaptation is essential to increase the resilience of agricultural production to climate change. Several improved agricultural practices evolved over time for diverse agroecological regions in India have potential to enhance climate change adaptation, if deployed prudently. Management practices that increase agricultural production under adverse climatic conditions also tend to support climate change adaptation because they increase resilience and reduce yield variability under variable climate and extreme events. Some practices that help adapt to climate change in Indian agriculture are soil organic carbon build up, in-situ moisture conservation, residue incorporation instead of burning, water harvesting and recycling for supplemental irrigation, growing drought and flood tolerant varieties, water saving technologies, location specific agronomic and nutrient management, improved livestock feed and feeding methods. Institutional interventions promote collective action and build resilience among communities. Capacity building by extensive participatory demonstrations of location specific agricultural practices helps farmers gain access to knowledge and provides confidence to cope with adverse weather conditions. In this project, an effort is made to marshall all available farm technologies that have adaptation potential and demonstrate them in farmers' fields in most vulnerable districts of the country through a participatory approach.

\section{Climate Resilience - An essential option}

In the field of ecology, resilience means building the capacity of a system to withstand shocks and to rebuild and respond to change, including unanticipated change

Climate resilience is the capacity of an individual, community, or institution to dynamically and effectively respond to shifting climate impact circumstances while continuing to function at an acceptable level. Simply put, it is the ability to survive and recover from the effects of climate change. It includes the ability to understand potential impacts and to take appropriate action before, during, and after a particular consequence to minimize negative effects and maintain the ability to respond to changing conditions.

Historically, the term adaptation has been used to describe the individual actions required to respond to climate change. The 
Intergovernmental Panel on Climate Change defines adaptation as an adjustment in natural or human systems in response to actual or expected climatic stimuli or their effects, an adjustment that moderates harm or exploits beneficial opportunities. We believe that resilience is a more accurate, positive, and comprehensive term, describing the dynamic, systemic transformation that is needed to respond to the consequences of climate change, especially future impacts that are difficult to predict.

\section{Elements of Resilience}

Climate change resilience requires the following elements:

Flexibility at an individual, organizational, and systemic level, with each level able to respond and contribute to each situation, and to respond to shifting and unpredictable circumstances.

A multi-faceted skill set, including abilities that enable thorough preparation, such as comprehensiveness and detail-orientation; survival, such as quick decision-making and resourcefulness; or rapid recovery, such as innovation and diligence.

Redundancy of processes, capacities, and response pathways within an institution, community, or system, to allow for partial failure within a system or institution without complete collapse.

Collaborative multi-sector approaches to planning, execution, and recovery, since no one sector has a monopoly on a particular impact and thus understanding the overlaps and gaps between sectors is critical.

Planning and foresight to prepare for identified impacts and risks. While it is impossible to plan for every possible set of impacts, and in many cases the cumulative effect of impacts is unknown, the process of planning brings learning, builds skills, and helps to create resilience.

Diversity and decentralization of planning, response, and recovery activities. A diversity of options has greater potential to match the particular scenario of impacts that occurs, while decentralization allows for parts of the system to continue operations even if other parts of the system are down.

Plans for failure so that break-downs happen gracefully, not catastrophically-for example, when flood gates break, they do so in a way that channels floodwaters to uninhabited floods zones, perhaps damaging property, but protecting human lives. Accepting that the unpredictability and uncertainty of climate risks and responses will ultimately lead to failure of some element of the system allows for failure-planning. In some cases returning to a pre-existing state will not be possible or will not be appropriate. Incremental failures and planning for failures will allow for realtime response and revision and will limit social, environmental, and economic costs.

Total system failure limits response options and results in greater suffering.

\section{Technological approaches towards climate resilient agriculture}

Building resilience in soil

Adapted cultivars and cropping systems

Rainwater harvesting and recycling

Water saving technologies

Farm machinery (custom hiring) centers

Crop contingency plans 
Weather based agro advisories

Weather based agro advisories

Village Climate Risk Management Committee (VCRMC)

\section{Building resilience in soil}

Soil health is the key property that determines the resilience of crop production under changing climate. A number of interventions are made to build soil carbon, control soil loss due to erosion and enhance water holding capacity of soils, all of which build resilience in soil.

Mandatory soil testing is done in all villages to ensure balanced use of chemical fertilizers. Improved methods of fertilizer application, matching with crop requirement to reduce nitrous oxide emission.

\section{Building soil carbon}

Even there is more sources like organic manure addition, green manuring, brown manuring, crop rotation or intercropping with legume sequester carbon, biochar has a unique property to sequester more carbon which is highlighted below.

Biochar is a fine-grained, carbon-rich, porous product remaining after plant biomass has been subjected to thermo-chemical conversion process (pyrolysis) at low temperatures $\left(\sim 350-600^{\circ} \mathrm{C}\right)$ in an environment with little or no oxygen (Amonette and Joseph, 2009).

\section{Avoid bare soil}

Removal of soil particles from the parent body and its transportation should be avoided, as it conserves soil fertility of that locality. So practice the following measures to conserve land degradation.
Land shaping - contour cultivation, land configuration, etc.

Cover vegetation in pastures and also avoid over grazing.

Mulching

Wind break \& Shelter belts

Strip cropping

\section{Tillage management}

Soil disturbance should be minimum. Use of more soil tilling implement causes erosion.

Tillage without adequate crop residue retention on the soil surface can lead to soil erosion by both wind and water leading to soil degradation. So go for reduced tillage i.e., conservation agriculture.

\section{Improved method of fertilizer application}

Fertilizer application should be done after mandatory soil testing. Some of the recent development is fertilizer application includes

SSNM and Leaf color chart for rice

Slow release fertilizer (coated urea)

Deep placement of urea

Fertigation

INM

\section{Adapted cultivars and cropping systems}

Farmers in the villages traditionally grow local varieties of different crops resulting in poor crop productivity due to heat, droughts or floods. Hence, improved, early duration drought, heat and flood tolerant varieties are introduced for achieving optimum yields despite climatic stresses. This varietal shift was carefully promoted by encouraging village level seed production and linking 
farmer's decision-making to weather based agro advisories and contingency planning.

\section{Selection of Variety}

Select an improved, short duration varieties according to the region, season, soils etc. with good yielding potential. For example use MDU-2 rice for low temperature condition.

\section{Section of a cropping sequence}

In a sequence, if the first crop is shallow rooted then the second crop should be deep rooted and vice versa.

Inclusion of legume is must

Avoid burning of crop residue in field, go for sowing using residual moisture.

\section{Crop diversification}

A farm with continuous monocropping will check the potential of that farm. So to make a farm dynamic and healthy, it has high diversity of plants and animals (above and below ground).

\section{Rainwater harvesting and recycling}

Rainwater harvesting and recycling through farm ponds, restoration of old rainwater harvesting structures in dryland / rainfed areas, percolation ponds for recharging of open wells, bore wells and injection wells for recharging ground water are taken up for enhancing farm level water storage.

\section{Inter-row water harvesting}

The crop sown in narrow strips between wide intervals that are ridged as artificial miniature watersheds. Usage of crop residues as mulch, application of coir pith enhance the water holding capacity of the soil.

\section{Inter-plot or micro plot water harvesting}

In this case water is harvested in the passage or furrows between the plots when rainfall is comparatively more. Runoff from the sloping area supplements rainfall for raising crop on level land.

\section{In farm ponds and reservoirs}

Surface runoff from small watersheds is stored in farm ponds for utilization as supplemental or lifesaving irrigation. Suitable lining material for pond beds and anti-evaporants should be found out and used.

\section{Recycling}

The water store in the farm ponds are recycled and used for raising second crop in dry spells. The field is watered using rain guns, sprinkler, drips etc. as the water use efficiency is high among them.

\section{Water saving technologies}

Since climate variability manifests in terms of deficit or excess water, major emphasis was laid on introduction of water saving technologies like direct seeded rice, zero tillage and other resource conservation practices, which also reduce GHG emissions besides saving of water.

Direct seeded rice

Drum seeded rice

Zero tillage

Micro irrigation

Improved planting measure like BBF, FIRB, etc.

Land configuration like tied ridges, tied furrows which arrest water. 


\section{Challenges before us}

\begin{tabular}{|l|l|l|}
\hline \multicolumn{1}{|c|}{ Particular } & 2030 & $\mathbf{2 0 5 0}$ \\
\hline Land (M.ha) & 141.3 & 131.3 \\
\hline Population (Crores) & 137 & 166 \\
\hline Food need (M.T) & 289 & 347 \\
\hline
\end{tabular}

\section{Building soil carbon}

\begin{tabular}{l|l|l}
\multicolumn{1}{c|}{ Factor } & \multicolumn{1}{c|}{ Impact } & \multicolumn{1}{c}{ Source } \\
\hline Cation exchange capacity & $50 \%$ increase & Glaser et al., 2002 \\
\hline Fertilizer use efficiency & $10-30 \%$ increase & Gaunt and Cowie, 2009 \\
\hline Soil moisture retention & Up to $18 \%$ increase & Tryon, 1948 \\
\hline Crop productivity & $20 \%$ increase & Lehman and Rondon, 2006 \\
\hline Methane Emission & $100 \%$ decrease & Rondon et al., 2005 \\
\hline Nitrous oxide emission & $50 \%$ decrease & Yanai et al., 2007 \\
Biological nitrogen fixation & $50-72 \%$ increase & Lehman and Rondon, 2006
\end{tabular}

Weather based agro advisories

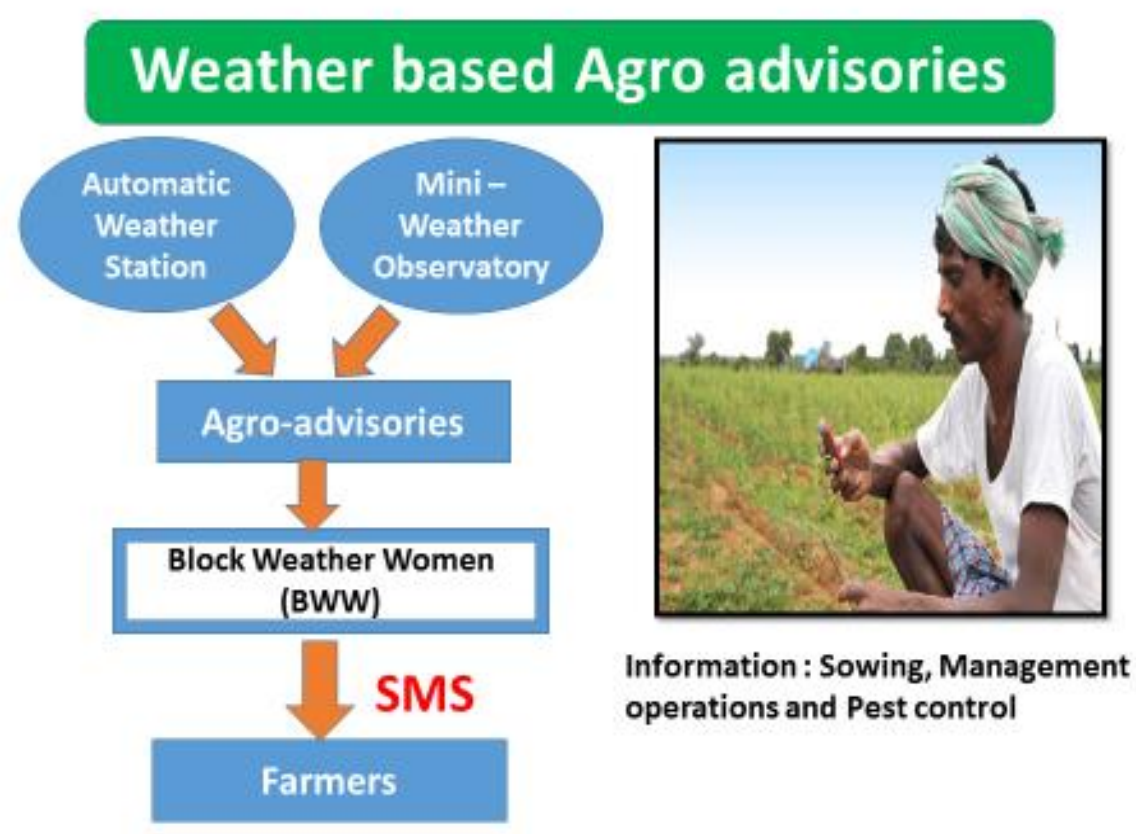

AICRPAM-NICRA (Bhuvaneshwar)

\section{Farm mechanization}

This is an important intervention to deal with variable climate like delay in monsoon, inadequate rains needing replanting of crops.
Community managed custom hiring centers are setup in each village to access farm machinery for timely sowing/planting. Machines used for common resilient practices include: 
Chisel plough and para plough help is opening furrows which conserves rain water.

Bund former and channel former help in taking up immediate planting/sowing

Laser leveler help in increasing nutrient and water use efficiency.

Direct seeder and drum seeder help in sowing at labour scarce time.

To use immediate rain we can opt for transplanters

Harvesters help in quick harvest of crop because of forecast of rain at maturity of crop.

Intercultivators give hands in labour shortage time

\section{Crop contingency plans}

To cope with climate variability, ICAR/CRIDA has developed district level contingency plans for our country at district level. Operationalization of these plans during aberrant monsoon years through the district/ block level extension staff helps farmers cope with climate variability.

Some of the plans include

\section{Seed village \& Community nursery}

All the inputs needed for raising crop from seed to seed production in a selected village / panchayat is given. With the help of extension staffs agro advisories, package of practices are given. After seed production, that seed is collected and distributed to the farmers at the time of seed crisis.

Seedlings are raised by a community of people to prevent land, time and availability of seedlings on time. For example using portrays for vegetable seedling.

\section{Community pond}

Renovation of community ponds by local people under MNREGS helps in raising ground water level, aids in bringing more area under cultivation etc.

\section{Pulse panchayat}

In Pudukottai under MSSRF, the farmers of one panchayat clubbed together to form a federation with the aim to combat protein hunger and adapting to drought. They took resolution to maximum area under pulse. This aided in pulse sufficiency of that panchayat.

\section{Livestock and fishery interventions}

Use of community lands for fodder production during droughts/floods, improved fodder/feed storage methods, feed supplements, micronutrient use to enhance adaptation to heat stress, preventive vaccination, improved shelters for reducing heat/cold stress in livestock, management of fish ponds/tanks during water scarcity and excess water are some key interventions in livestock/fishery sector.

\section{Weather based agro advisories}

Automatic weather stations at KVK experimental farms and mini-weather observatories in project villages are established to record real time weather parameters such as rainfall, temperature and wind speed etc. both to issue customized agro advisories and improve weather literacy among farmers.

\section{Institutional interventions}

Institutional interventions either by strengthening the existing ones or initiating new ones relating to seed bank, fodder bank, commodity groups, custom hiring centre, 
collective marketing, introduction of weather index based insurance and climate literacy through a village level weather station are introduced to ensure effective adoption of all other interventions and promote community ownership of the entire programme.

Advantages of custom hiring centers include:

Provides access to small and marginal farmers to costly farm machinery

Facilitates timeliness in farm operations and efficient use of inputs

Promotes adoption of climate resilient practices and technologies by farmers because of availability of appropriate machines at reasonable hiring charges

Reduce drudgery

Promotes increase in cropping intensity wherever feasible

Facilitates crop residue recycling and prevents burning of residues

Reduction in cost of cultivation

Provides work opportunities to skilled labour and small artisans

\section{Village Climate Risk Management Committee (VCRMC)}

A village committee representing all categories of farmers including women and the land less is formed with the approval of Gram Sabha to take all decisions regarding interventions, promote farmers participation and convergence with ongoing Government schemes relevant to climate change adaptation. VCRMC participates in all discussions leading to finalizing interventions, selection of target farmers and area, and liaison with gram panchayat and local elected representatives and maintain all financial transactions under the project. Millions of hungry and starving individuals hill have hope. We have their hopes vested in us. Despite our serious challenges, we still have hope. We need all support to elevate agriculture to achieve global climate change goals and the triple win of enhanced agricultural productivity and incomes, climate resilience and carbon sequestration. It is vital to include agriculture, food security and land in the climate change negotiation.

\section{References}

AU-NEPAD, 2010. The AU-NEPAD Agriculture Climate Change AdaptationMitigation Framework. CAADP, Pretoria, South Africa.

Chandran, S., Gopinath, K. A., Venkatesh, G., Dubey, A.K., Harsha Wakudkar, Purakayastha, T.J., Pathak, H., Pramod Jha, Lakaria, B.L., Rajkhowa, D.J., Sandip Mandal, Jeyaraman, S., Venkateswarlu, B. and Sikka, A.K. 2013. Use of biochar for soil health management and greenhouse gas mitigation in India: Potential and constraints, Central Research Institute for Dryland Agriculture, Hyderabad, Andhra Pradesh. 51p.

CSO [Central Statistical Organization]. 1998. Compendium on Environmental Statistics, Government of India, New Delhi.

DARE, 2009-2010, ICAR Annual Report 20092010, Chapter 4: Climate Change Food and Agriculture Organization of the United Nations (FAO), 2010, Globally Important Agricultural Heritage Systems (GIAHS), available at (http://www.fao.org/nr/giahs/giahshome/home-more/en/)

Das, T., et.al, Thermal tolerance of oxygen consumption of Indian major crops acclimated to four temperature, Journal of Thermal Biology, 29, 2004, pp-157-163 
FAO (2008).Crop Yield Response Factors Government of Maharashtra (2003) report on drought for 2002-03.

FAO, 2008. Preliminary map of land degradation, Food and Agriculture Organization of the United Nations, 2008.

FAO, 2010. "Climate-Smart' Agriculture Policies, Practices and Financing for Food Security, Adaptation and Mitigation. Food and Agriculture Organization of the United Nations, Rome.

Ghosh, Prodipto. (2009). "Is India a Solution to the Problem or a Problem to the Solution?", in NarainSunita, Ghosh Prodipto, SaxenaNC,ParikhJyoti and SoniPreet (Ed), "Climate Change: Perspectives from India", November, 2009, published by UNDP India.

GOI, 2004. India's Initial National Communication to the United Nations Framework Convention on Climate Change, Ministry of Environment and Forests, Government of India, New Delhi.

GOI, 2008, National Action Plan on Climate Change (NAPCC), GOI, 2008

GOI, 2009, Agricultural Statistics at a Glance, 2009, Ministry of Agriculture (MoA)

GOI, 2010, India: Green House Gas Emission2007, Ministry of Environment and Forest.

IARI, 2012. Crop residues management with conservation agriculture: Potential, constraints and policy needs. Indian Agricultural Research Institute, New Delhi, $32 \mathrm{p}$.

India Agricultural Census (2001) database India's national communication to UNFCCC (2004) Chapter 3, Vulnerability and Adaptation Indiastat (2008) database

Indian Institute of Management, Ahmedabad (IIM-A), 2006, Action Plan for National Agricultural Policy

IPCC, 2001. Climate change 2001: The scientific basis. Contribution of Working Group I to the Third Assessment Report of the Intergovernmental Panel on Climate Change (Houghton, J.T., Ding, Y., Griggs, D.J., Noguer, M., Vander Linden, P.J., Dai, X., Maskell, K. and
Johnson, C.A. (Eds.)), Cambridge University Press, Cambridge and New York.

IPCC, 2001: Climate Change 2001: Impacts, Adaptation and Vulnerability.

IPCC, 2007 (A): Agriculture. In Climate Change 2007: Mitigation Contribution of Working Group III to the Fourth Assessment Report of the Intergovernmental Panel on Climate Change, Cambridge University Press, Cambridge, United Kingdom and NewYork, NY, USA

IPCC, 2007. Climate Change 2007: Synthesis Report. International Panel on Climate Change.

IPCC, 2007: Climate Change 2007: Impacts, Adaptation and Vulnerability. Contribution of Working Group II to the Fourth Assessment Report of the Intergovernmental Panel on Climate Change, M.L. Parry, O.F. Canziani, J.P. Palutikof, P.J. van der Linden and C.E. Hanson, Eds., Cambridge University Press, Cambridge, UK, 976pp.

Krishna Kumar K, (2004) Climate Impacts on Indian Agriculture, Indian Journal of Climatology

Lobell and David(2007) Global-scale climatecrop yield relationships, Maharashtra irrigation department (2009) fact base National commission for enterprises in the unorganized sector (2008) Economic Survey of Maharashtra 2007-08

Maheswari, M., Srinivasarao, M., Ra o., V.U.M., Srinivasarao, CH., Reddy, K.S., Ramana, D.B.V., Ramana Rao, C.A., Vijay Kumar, P., Prasad, YG., Sikka, AK., Venkateswarlu, B., (2014). National Initiative on Climate Resilient Agriculture (NICRA), Research Highlights 20132104. Central Research Institute for Dryland Agriculture (ICAR), Hyderabad. $116 \mathrm{p}$.

Mathur Ajay (2009), "Ajay Mathur on Energy Efficiency in India", an interview with "The Climate Group", available at http://www.theclimategroup.org. Menon Purnima, Deolalikar Anil, BhaskarAnjor, 
Comparison of Hunger Across States: India State Hunger Index, International Food Policy Research Institute, USA, 2009 MoA, 2010, Annual Report 2009. 2010, Department of Agriculture and Cooperation, Ministry of Agriculture, Government of India

Narain Sunita (2009), “A Just Climate Agreement: The Framework for an Effective Global Deal” in Narain Sunita, Ghosh Prodipto, Saxena NC, Parikh Jyoti and Soni Preeti (Ed), "Climate Change: Perspectives from India", November, 2009, published by UNDP India

National Accounts Statistics, 2008. Central Statistical Organisation. Ministry of Statistics and Programme Implementation, New Delhi.

National Action Plan on Climate Change (NAPCC), 2008, Prime Minister's Council on Climate Change, Govt. of India, New Delhi.

National Council of Applied Economic Research (NCEAR), 2008

Nelson GC, Rosegrant MW, Palazzo A, Gray I, Ingersoll $\mathrm{C}$, Robertson $\mathrm{R}$, Tokgoz $\mathrm{S}$, Zhu T, Sulser T, Ringler C, Msangi S, You L, 2010. Food Security, Farming, and Climate Change to 2050: Scenarios, Results, Policy Options. IFPRI, Washington, DC.

Parikh Joyti (2009), "Gender: The ignored other half" in Narain Sunita, Ghosh Prodipto, Saxena NC, Parikh Jyoti and Soni Preeti (Ed), "Climate Change: Perspectives from India", November, 2009, published by UNDP India
Pathak H and Aggarwal PK (Eds) (2012). Low carbon technologies for Agriculture: A study on rice and wheat system in the Indo-Gangetic Plains, IARI, New Delhi 110012 , p.78

Prasad, YG, Maheswari, M., Dixit, S., Srinivasarao, CH., Sikka, A.K., Venkateswarlu, B., Sudhakar, N., Prabhu Kumar, S., Singh, AK., Gogoi, AK., Singh, AK., Singh, YV and Mishra, A. (2014). Smart Practices and Technologies for Climate Resilient Agriculture. Central Research Institute for Dryland Agriculture (ICAR), Hyderabad. 76 p.

Saikia US, Ramesh T, Ramkrushna GI, Krishnappa R, Rajkhowa DJ, Venkatesh $A$ and Ngachan SV (2014). Natural resource Management for enhancement of Adaptation and Mitigation Potential under Changing Climate. Edited book. Published by Director, ICAR Research complex for NEH region, Umiam, Meghalaya. 204 p.

Shelton, M., 2000. Reproductive performance of sheep exposed to hot environments. In: Malik, R.C., Razzaque, M.A., Al-Nasser, A.Y. (Eds.), Sheep Production in Hot and Arid Zones. Published by the Kuwait Institute for Scientific Research, pp. 155162.

Sinha, S.K., and M.S. Swaminathan, 1991: Deforestation, climate change and sustainable nutritional security: a case study of India. Climate Change, 19, 201209.

\section{How to cite this article:}

Mohan Kumar K., M. Hanumanthappa, Narayan S. Mavarkar and Marimuthu S. 2018. Review on Smart Practices and Technologies for Climate Resilient Agriculture. Int.J.Curr.Microbiol.App.Sci. 7(06): 3021-3031. doi: https://doi.org/10.20546/ijcmas.2018.706.355 